\title{
Assessing vulnerability: an integrated approach for mapping adaptive capacity, sensitivity, and exposure
}

\author{
Shawn W. Margles Weis ${ }^{1,3} \cdot$ Vera N. Agostini ${ }^{1,2}$ • \\ Lynnette M. Roth ${ }^{2} \cdot$ Ben Gilmer $^{1} \cdot$ Steven R. Schill $^{2}$ • \\ John English Knowles ${ }^{2} \cdot$ Ruth Blyther ${ }^{2}$
}

Received: 16 November 2014 / Accepted: 27 February 2016/Published online: 15 March 2016

(C) The Author(s) 2016. This article is published with open access at Springerlink.com

\begin{abstract}
Making decisions and efficiently allocating resources to reduce the vulnerability of coastal communities requires, among other things, an understanding of the factors that make a society vulnerable to climate and coastal hazards. One way of doing this is through the analysis of spatial data. We demonstrate how to apply GIS methods to spatially represent socioeconomic vulnerability in Grenada, a tropical small island developing state (SIDS) in the Eastern Caribbean. Our model combines spatial features representing variables of social sensitivity, community adaptive capacity, and community exposure to flooding in an integrated vulnerability index. We draw from the fields of climate change adaptation, disaster management, and poverty and development to select our variables enabling unique, cross sector, applications of our assessment. Mapping our results illustrates that vulnerability to flooding is not evenly distributed across the country and is not driven by the same factors in all areas of Grenada. This indicates a need for the implementation of different strategies in communities across Grenada to help effectively reduce vulnerability to climate and coastal hazards. The approach presented in this paper can be used to address national issues on climate change adaptation, disaster management, and poverty and development and more effectively utilize funds in order to reduce community vulnerability to natural hazards today and in the future.
\end{abstract}

Electronic supplementary material The online version of this article (doi:10.1007/s10584-016-1642-0) contains supplementary material, which is available to authorized users.

Shawn W. Margles Weis

Shawn.weis@tnc.org

1 The Nature Conservancy, Global Marine Team, Arlington, VA 22203, USA

2 The Nature Conservancy, Caribbean Program, Miami, FL, USA

3 Present address: The Nature Conservancy, Great Lakes - Michigan, 8 S Michigan Ave Suite 2301 Chicago, IL 60603, USA 


\section{Introduction}

Natural hazards from coastal storms, flooding, and rising sea level are increasing each year (Young et al. 2011) threatening human life and property (IPCC 2014). Countries and communities are considering their options to reduce the anticipated impacts. For developing countries, the costs associated with adaptation options are estimated to exceed US\$50 billion per year after 2020 (Smith et al. 2011). To assist these countries in developing mitigation and adaptation actions, developed nations have committed to mobilizing US\$100 billion by 2020 (Smith et al. 2011). As climate adaptation funding becomes increasingly available, developing countries must be prepared to act quickly to make investments in actions that have the most potential to reduce their vulnerability. Currently, funds are not always effectively invested and better methods are needed to design and select adaptation projects (Preston et al. 2011; Baker et al. 2012).

The utility of vulnerability assessments to identify priority activities for adaptation has been well documented (Moss et al. 2001; IPCC 2007; Cutter et al. 2009; Wongbusarakum and Loper 2011; and others). Vulnerability assessments can take many forms dependent on the field from which they are drawn (i.e., climate change adaptation, disaster risk management, or poverty and development). Climate change adaptation assessments tend to focus on social structures, such as the human condition or human processes, and aim to develop policies that will reduce risks associated with climate change (Füssel and Klein 2006). Disaster risk management assessments commonly focus on defining and quantifying damage ranges, typically to physical structures or number of people affected, so that levels of potential losses can be estimated and plans can be developed to achieve acceptable levels of loss and damage (Birkmann et al. 2013). Finally, poverty and development agencies often focus on present social, economic, and political conditions related to people or social systems rather than biophysical systems, seeking integration across a range of stresses and human capacities (Downing and Patwardhan 2004). The fields of climate adaptation, disaster management, and poverty and development have traditionally operated in separate silos; however, the interdependencies among these fields are increasingly clear (IPCC 2012).

The analysis of spatial information is key to the design of adaptation projects because the impacts of climate and hazards on communities vary across space (Eikelboom and Janssen 2013; IPCC 2012). Several examples of spatially assessing aspects of vulnerability exist at the local scale (Granger 2003; O’Brien et al. 2004; Shepard et al. 2012; and others). Although past efforts generally acknowledge exposure, sensitivity, and adaptive capacity as being part of overall vulnerability (Marshall et al. 2010; Wongbusarakum and Loper 2011, Mucke 2012), few studies have attempted to spatially model adaptive capacity (Holsten and Kropp 2012, Mucke 2012), and even fewer have combined all three aspects into a single spatial representation of vulnerability.

In this paper, we present a vulnerability assessment methodology that integrates exposure, sensitivity, and adaptive capacity into a spatial decision-making framework for Grenada, a small island developing state in the Eastern Caribbean. Drawing from and building upon existing indicator-based vulnerability assessments and mapping approaches from the fields of climate adaptation, disaster management, and poverty and development, we selected indicators that allow practitioners and managers from several fields to explore drivers of vulnerability at the national and sub-regional scale (Cutter et al. 2003; Granger 2003; O'Brien et al. 2004; Deressa et al. 2008; Marshall et al. 2010; Wongbusarakum and Loper 2011, Holsten and Kropp 2012, Mucke 2012; Shepard et al. 2012; Eikelboom and Janssen 2013). Our approach 
can be used to address national issues on climate change adaptation, hazard management, and poverty and development, and more effectively utilize funds in order to reduce community vulnerability to natural hazards today and in the future.

\section{Geographic context}

The country of Grenada $\left(12^{\circ} 07 \mathrm{~N}, 61^{\circ} 40 \mathrm{~W}\right)$ has a population of 105,540 (2011 census) and is comprised of the main island of Grenada, two smaller islands (Carriacou and Petite Martinique), and a number of smaller uninhabited and semi-inhabited cays. The total land area of the three primary islands is approximately $344 \mathrm{~km}^{2}$ and the highest elevation is $2757 \mathrm{ft}$. These islands mark the southern end of the Caribbean's Windward Islands, and they are among the youngest islands in the Insular Caribbean (Fig. 1). Despite its low latitude, Grenada has experienced several strong hurricanes in the last 15 years including Category 4 Hurricane Lenny in 1999, Category 3 Hurricane Ivan in 2004, and a number of smaller storms that have resulted in coastal and riverine flooding. These events have resulted in loss of life, loss of property, and damage to tourism infrastructure and agriculture areas that significantly impacted the country's economic growth. The country's highest population densities are located at low elevation, often right along the coast. The limited land, geographic location, scarce freshwater supplies, and high dependence on natural resource-based livelihoods (specifically tourism, fisheries, and agriculture) makes Grenada highly vulnerable to flooding from storm surge and permanent inundation from sea level rise.

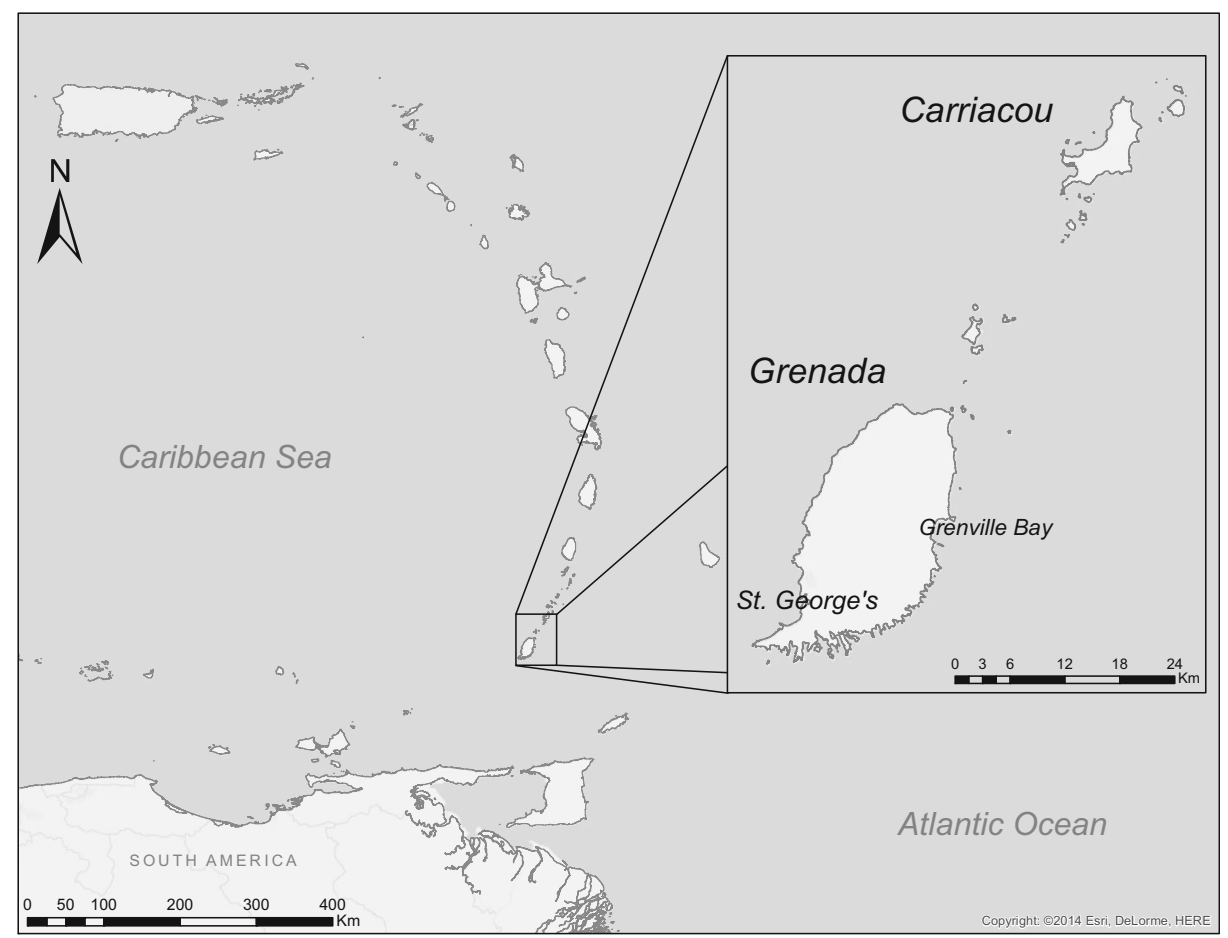

Fig. 1 Location map of Grenada 


\section{Study methods}

\subsection{Developing indices}

We developed a Vulnerability Index to measure the vulnerability of communities to flooding from present day storms as well as storms under possible future sea level scenarios. These types of flooding are environmental hazards of concern that were identified in previous studies and during in-country consultations (OECS 2004; Nurse et al. 2014). Following methods from Mucke (2012) and Shepard et al. (2012), we combined three sub-indices together to arrive at a final vulnerability index $(V)$ :

$$
V=E^{*} S^{*} A C
$$

where $E$ represents Exposure, $S$ represents Sensitivity, and $A C$ represents Adaptive Capacity (Adger 2006; IPCC 2007).

We reviewed indicator-based vulnerability studies from the fields of climate adaptation, disaster risk management, and poverty and development to construct the exposure, sensitivity, and adaptive capacity sub-indices (e.g., Moss et al. 2001; Cutter et al. 2003; Granger 2003; O’Brien et al. 2004; Deressa et al. 2008; Marshall et al. 2010; Wongbusarakum and Loper 2011, Holsten and Kropp 2012, Mucke 2012; Shepard et al. 2012; Eikelboom and Janssen 2013). While these three components are integrative concepts, useful for evaluating the potential effects of climate change, they are also complex concepts representing societal conditions that cannot always be directly measured or observed (Moss et al. 2001; Halpern et al. 2012). Therefore, following Moss et al. (2001) and others, we identified proxy indicators to construct our sub-indices. Initial indicators for our analysis were selected from those in the reviewed studies that were most applicable to Grenada and consisted of multiple variables that could be measured and spatially represented (e.g., length of road, number of households, and number of people; Table 1). Local experts reviewed and provided feedback on early versions of indicator and variable selections, which were then finalized via stakeholder workshops and meetings with in-country experts. The rationale for including each indicator in our analysis and how each indicator influenced total vulnerability can be found in the Supplemental Material, tables S1-S3.

\subsubsection{Exposure sub-index}

Exposure was defined as the degree to which a community experienced flooding from a given scenario (Marshall et al. 2010). The Exposure Sub-Index calculations were focused on storm surge scenarios and storm surge combined with sea level rise scenarios, assuming a linear increase. Generating complex and local non-linear sea-level rise estimates to be combined with storm surge scenarios was beyond the scope of this work and would require additional tidal information that was unavailable for the study area. Given the linear nature of the sea level rise estimates, it is expected that flooding outputs for some areas would be over-predicted, where other areas may be under-predicted, depending on local hydrological and geomorphological conditions. We used modeled levels of flooding from four different storm scenarios: 1) a 100 year flooding event with present day sea level; 2) a Hurricane Lenny type storm with present day sea level; 3) a Hurricane Lenny type storm with $1 \mathrm{~m}$ of sea level rise; and 4) a 
Table 1 Variables and indicators that make up the sub-indices of exposure, sensitivity, and adaptive capacity

\begin{tabular}{|c|c|c|c|}
\hline Sub-Index & Indicator & Variable & Source \\
\hline \multirow[t]{5}{*}{ Exposure } & $\begin{array}{l}\text { Critical facilities } \\
\text { exposure }\end{array}$ & $\begin{array}{l}\text { Percent of number of critical facilities } \\
\text { and infrastructure flooded (airports, } \\
\text { bus terminals, ferry terminals, ports, } \\
\text { sewage stations, water treatment } \\
\text { plants, cell towers, electricity plants, } \\
\text { fire stations, medical facilities, police } \\
\text { stations, emergency shelters) }\end{array}$ & Moss et al. 2001 \\
\hline & Road exposure & Percent of road length flooded & Moss et al. 2001 \\
\hline & Building exposure & Percent of building area flooded & Moss et al. 2001 \\
\hline & Livelihood exposure & $\begin{array}{l}\text { Percent of number of critical livelihood } \\
\text { facilities flooded (landing sites, fish } \\
\text { markets, ship-building, gear storage } \\
\text { facilities, fish processing plants, } \\
\text { hotels, dive shops) }\end{array}$ & $\begin{array}{l}\text { Moss et al. 2001, } \\
\text { Granger } 2003\end{array}$ \\
\hline & Community exposure & $\begin{array}{l}\text { Percent of number of community } \\
\text { facilities flooded (religious centers, } \\
\text { financial institutions, schools, } \\
\text { cemeteries) }\end{array}$ & $\begin{array}{l}\text { Moss et al. 2001, } \\
\text { Granger } 2003\end{array}$ \\
\hline \multirow[t]{9}{*}{ Sensitivity } & \multirow[t]{4}{*}{$\begin{array}{l}\text { Access to critical } \\
\text { infrastructure and } \\
\text { facilities }\end{array}$} & $\begin{array}{l}\text { Access to transportation terminals } \\
\text { (number of terminals per } 100 \text { people: } \\
\text { airports, bus, ferry, and port } \\
\text { terminals) }\end{array}$ & \multirow[t]{4}{*}{$\begin{array}{l}\text { Moss et al. 2001, Cutter } \\
\text { et al. 2003, Granger } \\
\text { 2003, Shepard et al. } \\
2012\end{array}$} \\
\hline & & $\begin{array}{l}\text { Access to critical facilities (number of } \\
\text { facilities per } 100 \text { people: water } \\
\text { treatment plants, cell towers, } \\
\text { electricity plants, sewage stations) }\end{array}$ & \\
\hline & & $\begin{array}{l}\text { Access to emergency response } \\
\text { (emergency response options per } 100 \\
\text { people: fire, police, medical, } \\
\text { hurricane shelters) }\end{array}$ & \\
\hline & & $\begin{array}{l}\text { Access to roads (number of people per } \\
\text { road mile) }\end{array}$ & \\
\hline & \multirow[t]{3}{*}{$\begin{array}{l}\text { Dependent } \\
\text { demographic Groups }\end{array}$} & $\begin{array}{l}\text { Percent of population that is very old or } \\
\text { very young }\end{array}$ & \multirow[t]{3}{*}{ Shepard et al. 2012} \\
\hline & & $\begin{array}{l}\text { Percent of population without access to } \\
\text { vehicles }\end{array}$ & \\
\hline & & $\begin{array}{l}\text { Percent of the population without access } \\
\text { to emergency information }\end{array}$ & \\
\hline & \multirow{2}{*}{$\begin{array}{l}\text { Livelihood dependence } \\
\text { on marine goods and } \\
\text { services }\end{array}$} & $\begin{array}{l}\text { Dependence on fisheries for jobs } \\
\text { (percent of workforce in fisheries) }\end{array}$ & \multirow[t]{2}{*}{$\begin{array}{l}\text { Wongbusarakum and } \\
\text { Loper } 2011\end{array}$} \\
\hline & & $\begin{array}{l}\text { Dependence on tourism for jobs (percent } \\
\text { of workforce in tourism) }\end{array}$ & \\
\hline \multirow{6}{*}{$\begin{array}{l}\text { Adaptive } \\
\text { capacity }\end{array}$} & \multirow{3}{*}{$\begin{array}{l}\text { Human and civic } \\
\text { resources }\end{array}$} & Percent of population in workforce & \multirow{3}{*}{$\begin{array}{l}\text { Moss et al. 2001, } \\
\text { O'Brien et al. 2004, } \\
\text { Marshall et al. 2010, } \\
\text { Wongbusarakum and } \\
\text { Loper } 2011\end{array}$} \\
\hline & & $\begin{array}{l}\text { Access to social networks (community } \\
\text { facilities per } 100 \text { people) }\end{array}$ & \\
\hline & & Percent of population educated & \\
\hline & \multirow[t]{3}{*}{ Healthy population } & Percent of population with health insurance & \multirow{3}{*}{$\begin{array}{l}\text { Moss et al. 2001, } \\
\text { Marshall et al. } 2010\end{array}$} \\
\hline & & $\begin{array}{l}\text { Level of disabilities (number of } \\
\text { disabilities per } 100 \text { people) }\end{array}$ & \\
\hline & & Infant mortality rate & \\
\hline
\end{tabular}


Table 1 (continued)

\begin{tabular}{|c|c|c|c|}
\hline Sub-Index & Indicator & Variable & Source \\
\hline & Economic resources & $\begin{array}{l}\text { Percent of population with property } \\
\text { insurance } \\
\text { Access to supplemental livelihood } \\
\text { (share of population with access to } \\
\text { multiple industries) }\end{array}$ & $\begin{array}{l}\text { Moss et al. 2001, } \\
\text { O’Brien et al. 2004, } \\
\text { Marshall et al. 2010, } \\
\text { Wongbusarakum and } \\
\text { Loper } 2011\end{array}$ \\
\hline
\end{tabular}

Hurricane Lenny type storm with $2 \mathrm{~m}$ of sea level rise (section 4.3 of the Supplemental Material details how each flooding layer was created). A Hurricane Lenny type storm was identified during pre-analysis stakeholder workshops as a storm surge scenario of particular interest under future sea level scenarios.

As we wanted to capture exposure to people and key infrastructure supporting livelihoods and vital functions of a community, we chose indicators that represented physical aspects of communities as a proxy to determine total flooding of communities. Specifically, we calculated the percentage of flooded 1) road length; 2) building area; 3) critical facilities; 4) important livelihoods structures; and 5) community infrastructure to create an Exposure Sub-Index for each flooding scenario (Table 1).

\subsubsection{Sensitivity sub-index}

Sensitivity captures characteristics of a community that influence its likelihood to experience harm under a given stressor scenario (e.g., storm, drought, sea level rise; Marshall et al. 2010). There are many different dimensions of sensitivity including physical, economic, social, environmental, and cultural (Moss et al. 2001). Given the scope of this project, we mapped two dimensions of community sensitivity to flooding: economic and social. We captured the two dimensions via three indicators: 1) access to critical infrastructure facilities; 2) dependent demographic groups; and 3) livelihood dependence on marine goods and services (Table 1).

\subsubsection{Adaptive capacity sub-index}

Adaptive capacity is a function of both asset based components of a community such as wealth and human capital (Moss et al. 2001) as well as less tangible aspects such as flexibility, innovation, redundancy, and perception of options (Yohe and Tol 2002, Marshall et al. 2010; Wongbusarakum and Loper 2011). This component of vulnerability captures the sometimes intangible elements of a community which predict how flexible individuals may be in anticipating, responding to, coping with, and recovering from climate impacts (Smit and Wandel 2006). This can include adapting to new employment opportunities or shifts in living patterns brought about by climate variability or catastrophic events. For our Adaptive Capacity Sub-Index, we mapped asset-based resource indicators of adaptive capacity using information on: 1) human and civic resources; 2) healthy population as a resource; and 3) economic resources (Table 1). Capturing the less tangible aspects such as flexibility and innovation would have required additional time and resources that were beyond the scope of this work. 


\subsection{Data collection}

Data used in our analysis can be categorized as: 1) digitized features; 2) census information; and 3) modeled flood scenarios. Several data layers were digitized from orthorectified WorldView2 2010 photos or collected through interviews with local experts, GPS tracking, and digitization. The Grenada Statistical Department provided 2011 census data (the most recent census survey date) in a raw table format at the enumeration district level. Modeled storm surge scenarios were generated using the Maximum Envelope of High Water (MEOHW) method. Additional details on the source and methods for creating each data layer used in this analysis are provided in section 4 of the Supplemental Materials.

\subsection{Calculating indices}

Following Mucke (2012) and Shepard et al. (2012) each variable contributed equally to its indicator as did each indicator to its sub-index score. The variables within each of the indicators that make up the Exposure Sub-Index were already normalized due to the physical limits of exposure $(0=$ no exposure, and $1=$ full exposure $)$. Since the variables within each of the indicators that make up Sensitivity and Adaptive Capacity Sub-Indices did not have fully defined physical limits, we had to normalized the values for each variable by scaling them from 0 to 1 , with 0 representing the positive end (low sensitivity and high adaptive capacity) by choosing values for the variable that represent the best and worst case. The limits were chosen to maximize variability and usually relied on the physical limits of the data that made up the variable.

Variables could have either a positive direction (e.g., number of people with access to social networks, where a higher number indicates lower vulnerability) or negative direction (e.g., number of people without access to vehicles, where a higher number indicates greater vulnerability) which affected the type of scaling equation needed. There were also two different categories of variables: relative and absolute. The majority of variables were relative, meaning they were a unit-less, ratio dataset (i.e., percentages). For these variables, two scaling equations were used depending on the direction of the variable. The standard scale took the value and divided it by the maximum value of all the enumeration districts:

$$
\text { Scale }=\mathrm{V} / \operatorname{Max}(\mathrm{V} \text { all EDs })
$$

where $\mathrm{V}$ is the calculated value of the variable. The second equation for reverse scaling was 1 minus the value divided by 1 minus the minimum value of all the enumeration districts:

$$
\text { Scale }=(1-\mathrm{V}) /[1-\mathrm{Min}(\mathrm{V} \text { of all EDs })]
$$

where $\mathrm{V}$ is the calculated value of the variable.

The absolute variables maintained their units prior to scaling, and therefore needed to be scaled differently. In our analysis, we had 5 such variables, all of which were a ratio of the number of buildings (of a given type) per 100 people (Table 1). All of these variables also had positive directionality so only one scaling equation was needed. The equation was the maximum value of all the enumeration districts minus the value divided by the maximum value:

$$
\text { Scale }=[\operatorname{Max}(\mathrm{V} \text { of all EDs })-\mathrm{V}] / \operatorname{Max}(\mathrm{V} \text { of all EDs })
$$


where $\mathrm{V}$ is the calculated value of the variable. Due to the larger uncertainty in the physical limits of the absolute variables, these variables can produce potentially misleading results. The small number of absolute variables minimizes the impact of this issue in the overall results, though it should be considered when analyzing indicators that are dominated by absolute variables (i.e., Access to Critical Infrastructure and Facilities within the Sensitivity Sub-Index). Additional details on our scaling methodology can be found in section 2 of the Supplemental Materials.

Following Mucke (2012) and Shepard et al. (2012), each sub-index was calculated and then multiplied to generate a final Vulnerability Index (Eq. 1) for each flooding scenario. As a result of the above process of data scaling, the final vulnerability values are relative. Similar to other studies like Holsten and Kropp (2012), this means that no absolute conclusions can be drawn concerning the final vulnerability values (e.g., enumeration district $\mathrm{X}$ is vulnerable, or enumeration $\mathrm{X}$ is twice as vulnerable as $\mathrm{Y}$ ). The correct conclusions are relative statements for the study area (e.g., enumeration district $\mathrm{X}$ has a higher vulnerability than Y). Additional details on how individual variables and indicators were measured and mathematically calculated are included in section 2 of the Supplemental Materials.

\subsection{Mapping}

In order to spatially represent our indices, we chose the highest resolution boundary that we could collect data for as a base summary unit: the 2011 enumeration district boundary dataset from the Grenada Statistical Department. For the 2011 census, there were 287 districts for the entire nation. Data for each of our variables were joined to the spatial district layer. Out of the 287 enumeration districts, only one had no residential component and therefore no census data. This district was excluded from the analysis and is represented as "No Data" in the figures. To spatially represent and visually compare results, the Vulnerability Index and the sub-indices were displayed using a 5 category quantile split within ArcGIS ${ }^{\circledR} 10.1$ (Figs. 2-5). In order to compare among the different flooding scenarios, the four scenarios within the Exposure Sub-Index and the final Vulnerability Index had the same ranges for each of the 5 categories which was set to the scenario with the smallest range (i.e., Hurricane Lenny type storm at present day sea level). All analysis layers and maps that could be publicly shared based on confidentiality agreements with data providers were posted to http://maps. coastalresilience.org/gsvg/.

\section{Results}

\subsection{Vulnerability}

Because an area is not vulnerable in our model unless it is exposed to flooding, total vulnerability is very dependent on elevation and slope in an area. Our analysis consistently highlights the same coastal areas as being vulnerable to flooding from storms both at present day sea level and storms under future sea level scenarios: the southeastern coastal areas, the Grenville Bay area on the central east coast of the main island of Grenada, and the island of Carriacou (Fig. 2). Vulnerability is not driven by the same indicators in all areas of Grenada. For example, the vulnerability of Grenville Bay to a 100 year flood is driven by relatively high 


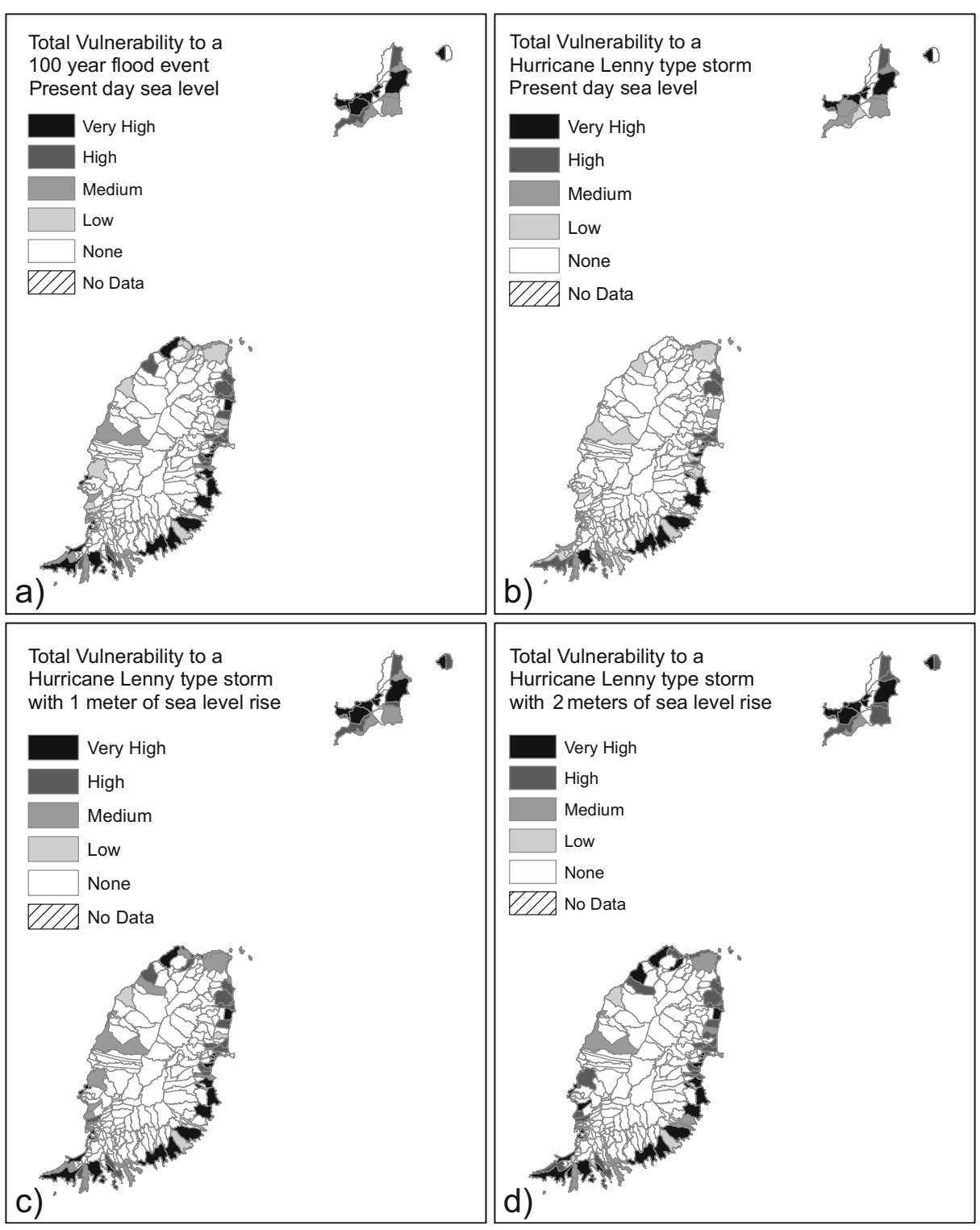

Fig. 2 Total Vulnerability Index by enumeration district to four different flooding scenarios: a) a 100 year storm under present day sea level, b) a Hurricane Lenny type storm under present day sea level, c) a Hurricane Lenny type storm with $1 \mathrm{~m}$ of sea level rise and d) a Hurricane Lenny type storm with $2 \mathrm{~m}$ sea level rise. A five category quantile classification was applied to the scenario with the smallest vulnerability range (Hurricane Lenny type storm at present day sea level). The same category values were then applied to the other 3 scenarios to allow for comparison

exposure and relatively low adaptive capacity, with relatively high to very high sensitivity also contributing to vulnerability along the southern coast of the bay. By comparison, the vulnerability of St. George's is driven by exposure and medium to high sensitivity, while its adaptive capacity is relatively high to very high (Fig. 3). 


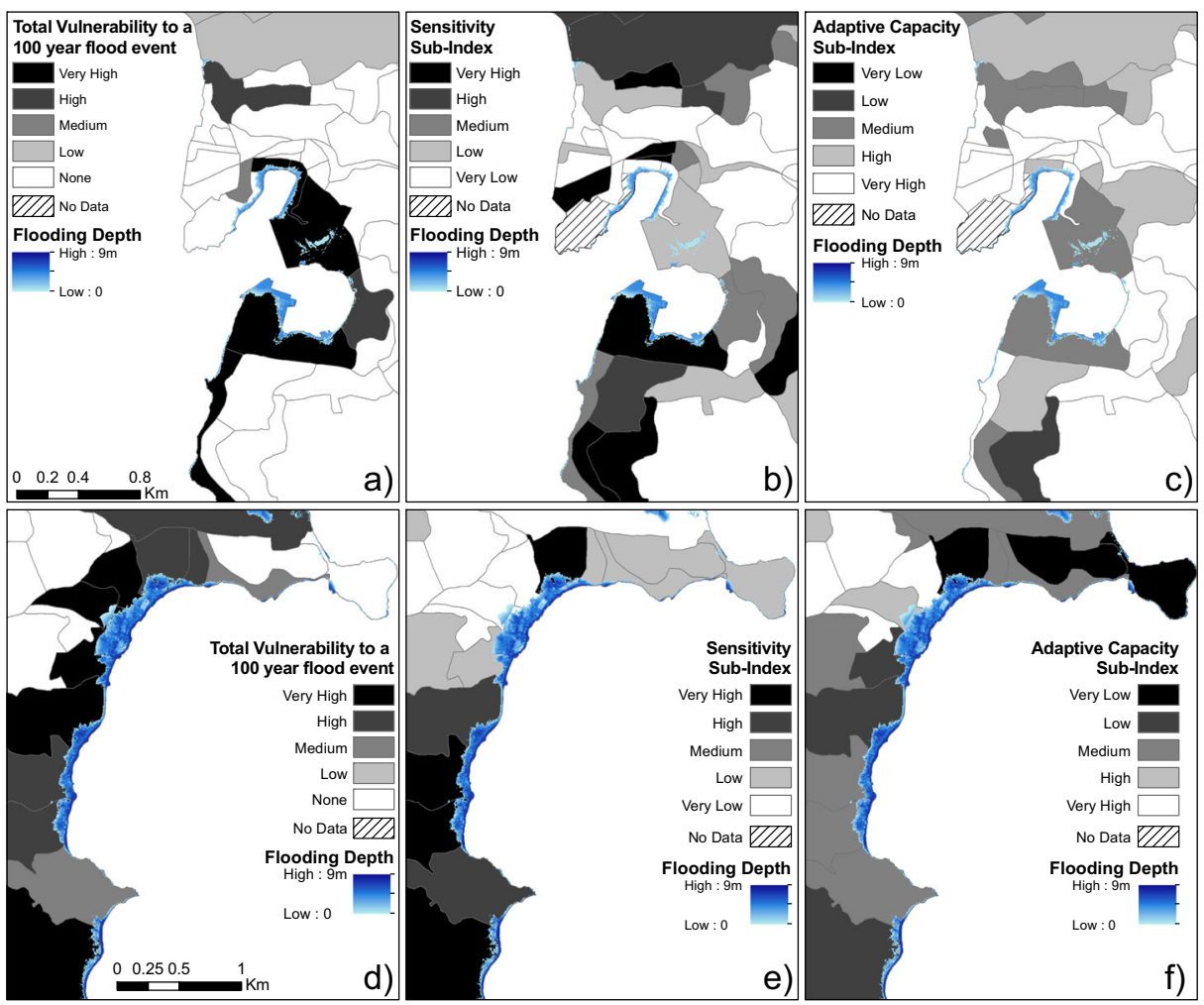

Fig. 3 Analysis results for the region of a-c St. George's and $\mathbf{d}-\mathbf{f}$ Grenville Bay displaying the Vulnerability Index, Sensitivity Sub-Index, and Adaptive Capacity Sub-Index respectively along with water depths of the 100 year flood scenario as a representative Exposure layer

\subsection{Exposure}

Nationally, our analysis across the four scenarios shows a strong pattern of exposure to flooding from storms along the east coasts of the main island of Grenada and the smaller island of Carriacou (Fig. 4). The east coast of Grenada is likely to experience more exposure from hurricanes as these storm systems typically move across the Atlantic Ocean in an eastnorth-eastwardly direction. Also, the east coast of Grenada, being at comparatively lower lying elevations than the west coast, has relatively more features at risk to flooding. Across scenarios, the percent of enumeration districts to experience some level of flooding ranged from 22 to $34 \%$; the greatest percent of flooded districts occurred under the Hurricane Lenny with $2 \mathrm{~m}$ sea level rise scenario $(34 \%, n=99)$ and the least amount of flooding $(22 \%, n=22)$ occurring under the Hurricane Lenny scenario with present day sea level (Table 2). The maximum level of flooding within an enumeration district was nearly $80 \%$, which occurred under a Hurricane Lenny type storm with $2 \mathrm{~m}$ of sea level rise.

\subsection{Sensitivity and adaptive capacity}

The spatial patterns of sensitivity and adaptive capacity are different between the two subindices. The pattern of sensitivity varies greatly across Grenada while there are concentrated 


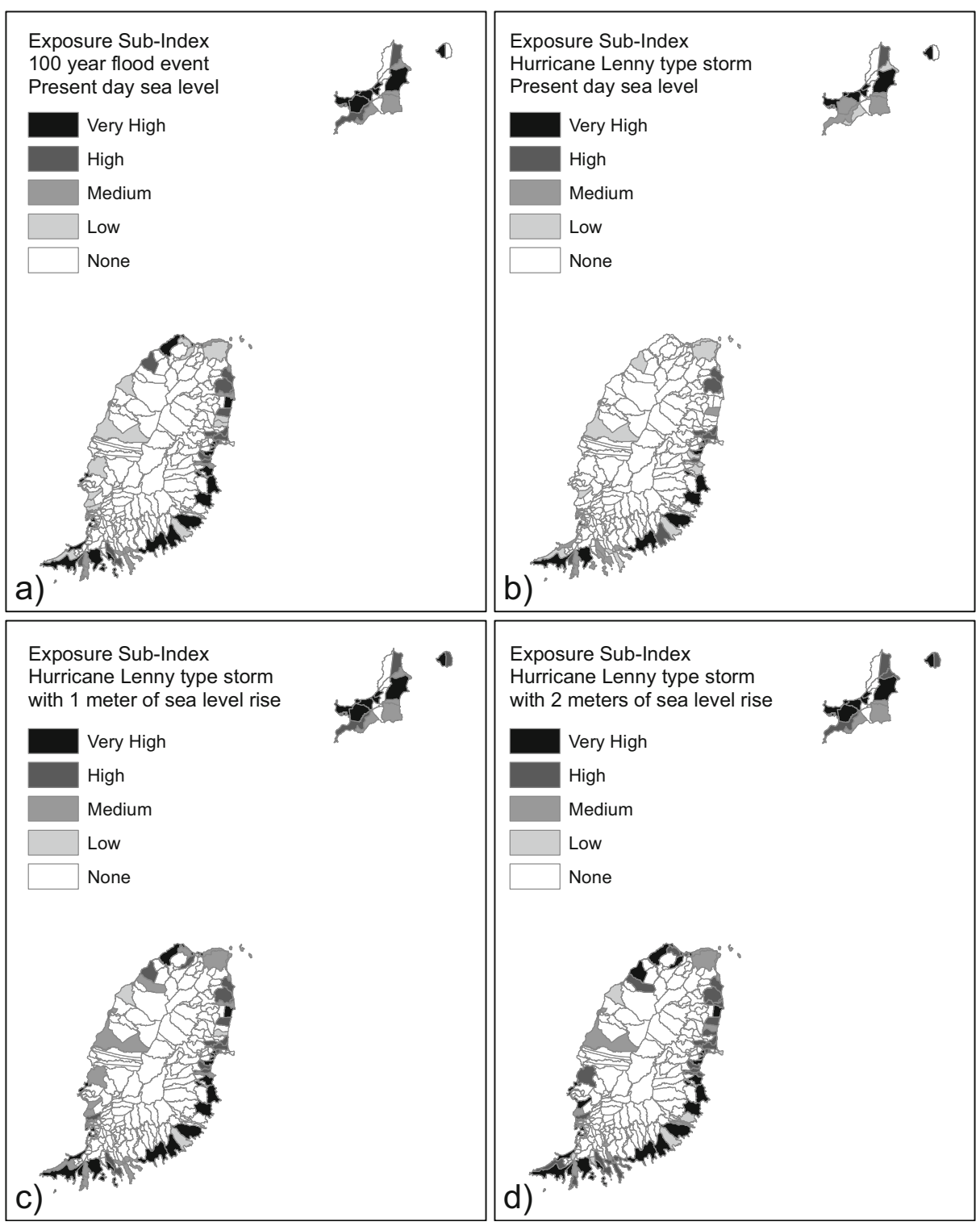

Fig. 4 Comparison of exposure by enumeration district from four different flooding scenarios: a) a 100 year storm under present day sea level, b) a Hurricane Lenny type storm under present day sea level, c) a Hurricane Lenny type storm with $1 \mathrm{~m}$ sea level rise and d) a Hurricane Lenny type storm with $2 \mathrm{~m}$ sea level rise. A five category quantile classification was applied to the scenario with the smallest exposure range (Hurricane Lenny type storm at present day sea level). The same category values were then applied to the other 3 scenarios to allow for comparison

regions of low adaptive capacity in the northeast quadrant and mountainous regions of the main island of Grenada, with an additional concentration of low adaptive capacity in the southeast quadrant (Fig. 5). The coastal areas of low adaptive capacity roughly correspond with areas of high exposure to our flooding scenarios (Figs. 4 and 5), 
Table 2 Exposure of enumeration districts including total and percentage districts flooded and maximum district flooding for each scenario

\begin{tabular}{|c|c|c|c|c|c|c|c|}
\hline Inundation scenario & $\begin{array}{l}\text { Total exposed } \\
(\%)\end{array}$ & $\begin{array}{l}\text { Very high } \\
(\%)\end{array}$ & $\begin{array}{l}\text { High } \\
(\%)\end{array}$ & $\begin{array}{l}\text { Medium } \\
(\%)\end{array}$ & Low $(\%)$ & None $(\%)$ & $\begin{array}{l}\text { Max. \% } \\
\text { community } \\
\text { inundation }\end{array}$ \\
\hline 100 year flood & $83(29 \%)$ & $33(10 \%)$ & $21(7 \%)$ & $16(6 \%)$ & $16(6 \%)$ & $204(71 \%)$ & $74 \%$ \\
\hline $\begin{array}{l}\text { Hurricane Lenny } \\
\text { type storm }\end{array}$ & $62(22 \%)$ & $15(5 \%)$ & $15(5 \%)$ & $15(5 \%)$ & $17(6 \%)$ & $225(78 \%)$ & $35 \%$ \\
\hline $\begin{array}{l}\text { Hurricane Lenny } \\
\text { type storm with } \\
1 \mathrm{~m} \text { sea level rise }\end{array}$ & $92(32 \%)$ & $33(11 \%)$ & $29(10 \%)$ & $23(8 \%)$ & $7(2 \%)$ & $195(68 \%)$ & $63 \%$ \\
\hline $\begin{array}{l}\text { Hurricane Lenny } \\
\text { type storm with } \\
2 \mathrm{~m} \text { sea level rise }\end{array}$ & $99(34 \%)$ & $41(14 \%)$ & $36(13 \%)$ & $15(5 \%)$ & $7(2 \%)$ & $188(66 \%)$ & $79 \%$ \\
\hline
\end{tabular}

\section{Discussion}

Our analysis suggests that in order to reduce the risk in Grenada posed by flooding from storm surge at present day sea level, and possible sea levels in the future, high priority areas for investments are the southeastern coastal areas, the Grenville Bay area on the central east coast of the main island of Grenada, and the island of Carriacou. While these particularly vulnerable areas may have been previously identified, the specific type of actions to implement remained

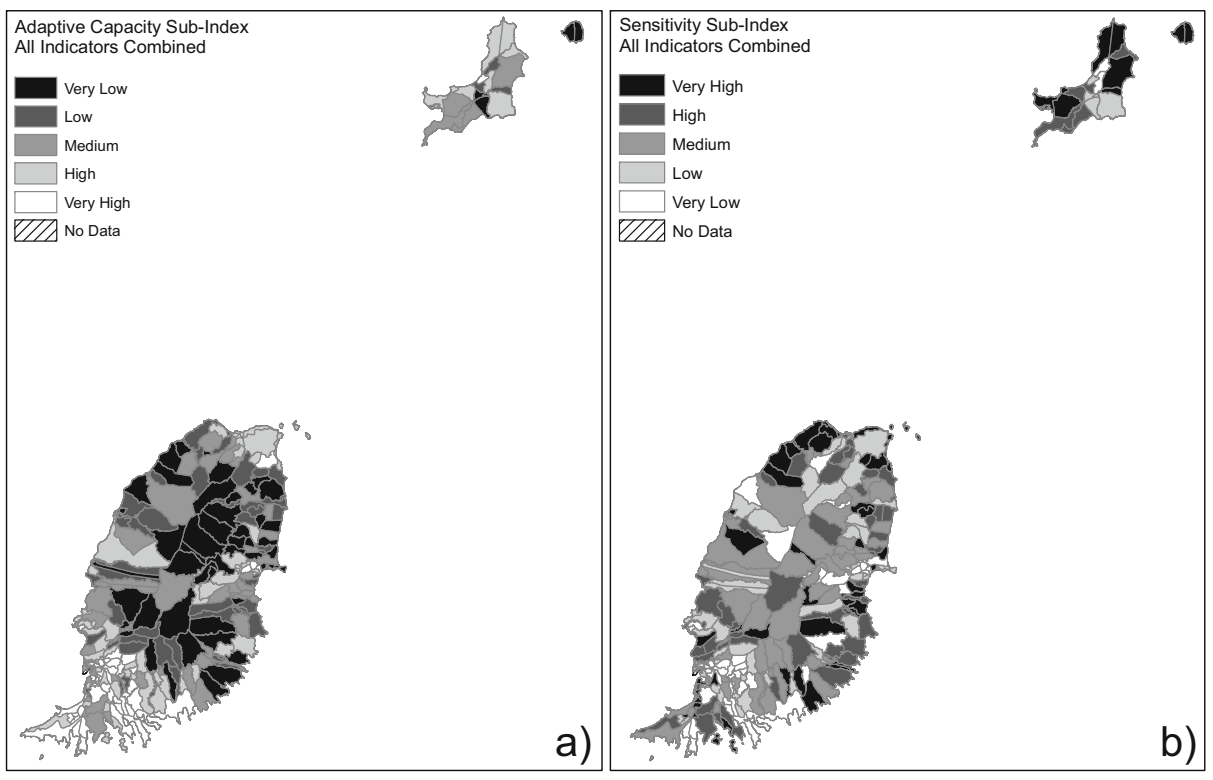

Fig. 5 Adaptive Capacity and Sensitivity Sub-Indices spatially displayed by enumeration district. a) Adaptive Capacity Sub-Index. b) Sensitivity Sub-Index. A five category quantile classification was applied to each SubIndex to generate 'very high' to 'very low' categories 
elusive. Our results suggest that a variety of approaches will be required to reduce the vulnerability to coastal hazards of these coastal communities, with specific actions appropriate for each area. For example, the Grenville Bay results suggest that a focus on investments to increase adaptive capacity is appropriate while the St. George's results suggest a focus on investments to help decrease sensitivity is appropriate. The individual indicators of these subindices (for example human and civic resources for adaptive capacity and critical infrastructure for sensitivity) were not spatially presented in this paper, but can further lead to suggestions on specific actions in those areas. All indicators are available on http://maps.coastalresilience.org/ gsvg/. As expected, it is clear that flooding from short term events (storm surge) and slow onset climate change induced events (sea levels rise) have cumulative impacts so managers tasked with designing actions to help reduce impacts from these should work together.

By integrating exposure, sensitivity, and adaptive capacity into a single spatial framework, decision makers are able to explore the different components of vulnerability at the national and sub-regional scale. The methodology we developed allows for mapping of both cumulative vulnerability as well as individual representations of exposure, sensitivity, and adaptive capacity. By drawing from the fields of disaster management, climate adaptation, and poverty and development we use a variety of indicators and variables that can be recognized, understood, and used by diverse practitioners. Our results illustrate how this methodology can be used to address community adaptive capacity, sensitivity, or exposure depending on their relative contribution to overall vulnerability. The individual indicator maps available on http://maps.coastalresilience.org/gsvg/ help generate an even more complete understanding of the factors contributing to overall vulnerability, and the relationship between them, potentially leading to further focused action. For example, reviewing the indicator maps that represent an area as particularly high in sensitivity due to the lack of critical infrastructure (as opposed to critical facilities), can guide focused investments toward critical infrastructure as opposed to diffuse investments towards improving all of the factors that describe sensitivity.

While many approaches to assess regional vulnerability are useful, they frequently rely on global datasets and predictive climate models that make country specific interpretation difficult due to variations in existing local conditions. Furthermore, indicator-based approaches can be limited by the quality and quantity of available data. Apart from the flooding scenarios, our methodology relies on data collected by national agencies, local NGO's, and local GIS professionals making the information generated relevant to a local context and enabling local decision makers to maintain and update these assessments. Given the similarities in data collection methodologies used by agencies across the Caribbean (e.g., census), our methods could be replicated across the region.

There are a number of gaps in our study we would like to highlight. The different indicators represented in our framework likely contribute to the overall vulnerability to varying degrees, depending on local context. In an attempt to maintain objectivity we weighed all indicators equally, especially given that our stakeholder discussions did not lead to clear differences in contributions amongst them to overall vulnerability. A deeper investigation into how the local context influences the relationship between indicators would strengthen our approach. In addition, given the impacts on the region from other climate related exposure (e.g., drought, fire, and others), including a suite of indicators that captures the exposure and related sensitivities of these stressors would be useful. However, our work was designed to provide a flexible framework able to incorporate additional exposure scenarios from a variety of climate stressors as the appropriate indicators are identified and quantified. Governance plays 
a critical role in the design of any disaster management and adaptation action, so indicators to represent this should be included in future iterations. Also, further work could be conducted to quantify economic value of individual features represented, which would allow for a dollar estimation of potential impacts from climate and disasters on coastal communities. Finally, our study only considers marine flooding; as sea-level rises, so does the groundwater below. Future research should consider groundwater modeling so that the effect of storm surge on groundwater levels can be examined (Cooper et al. 2015).

In a time of relatively rapid global environmental change, understanding the nuances of vulnerability and risk can be daunting. Approaches are needed that will enable countries and local managers to more easily digest information to help inform local action and funding decisions for climate adaptation, disaster risk reduction, and poverty and development. These decisions will only become more pressing as additional funding becomes available under existing international agreements (Smith et al. 2011). As these funds are released for Grenada, projects and actions will need to be evaluated; our results can help guide effective allocation of resources and suitable locations for potential adaptation and disaster risk reduction projects. For example, an aid organization interested in focusing on investments to increase adaptive capacity in Grenada could use the results of our study to identify appropriate sites where the lack of these attributes contributes most to overall vulnerability. Our study provides a model for how to develop tools that will ultimately help countries, especially SIDS and developing countries, more effectively utilize funds that are becoming available to support decision making across the climate adaptation, disaster management, and poverty and development sectors.

Acknowledgments A generous anonymous donor supported this project. We would like to acknowledge and thank our in-country partners including the Grenada Statistics Department, National Disaster Management Agency, Department of Fisheries, The Grenada Red Cross Society, Grenada Fund for Conservation, Juliana Castaño Isaza, Martin Barriteau, Alan Joseph, and Jerry Mitchell. We would also like to thank Jacob Roth for assistance with mathematical interpretations.

Open Access This article is distributed under the terms of the Creative Commons Attribution 4.0 International License (http://creativecommons.org/licenses/by/4.0/), which permits unrestricted use, distribution, and reproduction in any medium, provided you give appropriate credit to the original author(s) and the source, provide a link to the Creative Commons license, and indicate if changes were made.

\section{References}

Adger WN (2006) Vulnerability. Glob Environ Chang 16:268-281

Baker I, Peterson A, Brown G, McAlpine C (2012) Local government response to the impacts of climate change: An evaluation of local climate adaptation plans. Landsc Urban Plan 107:127-136

Birkmann J, Cardona OD, Carreño ML, Barbat AH, Pelling M, Schneiderbauer S, Kienberger S, Keiler M, Alexander D, Zeil P, Welle T (2013) Framing vulnerability, risk and societal responses: the MOVE framework. Nat Hazards 67:193-211

Cooper HM, Zhang C, Selch D (2015) Incorporating uncertainty of groundwater modeling in sea-level rise assessment: a case study in South Florida. Clim Chang 129:281-294

Cutter SL, Boruff BJ, Shirley WL (2003) Social vulnerability to environmental hazards. Soc Sci Q 84:242-261

Cutter SL, Emrich CT, Webb JJ, Morath D (2009) Social vulnerability to climate variability hazards: a review of the literature. Report to Oxfam America, Final

Deressa T, Hassan RM, Ringler C (2008) Measuring Ethiopian farmers' vulnerability to climate change across regional states, International Food Policy Research Institute (IFPRI). Washington, DC

Downing T, Patwardhan A (2004) Assessing vulnerability for climate adaptation. Cambridge University Press, Cambridge, United Kingdom 
Eikelboom T, Janssen R (2013) Interactive spatial tools for the design of regional adaptation strategies. J Environ Manag 127:S6-S14

Füssel H-M, Klein RJT (2006) Climate change vulnerability assessments: an evolution of conceptual thinking. Clim Chang 75:301-329

Granger K (2003) Quantifying storm tide risk in Cairns. Nat Hazards 30:165-185

Halpern BS, Longo C, Hardy D, McLeod KL, Samhouri JF, Katona SK, Kleisner K, Lester SE, O'Leary J, Ranelletti M, Rosenberg AA, Scarborough C, Selig ER, Best BD, Brumbaugh DR, Chapin FS, Crowder LB, Daly KL, Doney SC, Elfes C, Fogarty MJ, Gaines SD, Jacobsen KI, Karrer LB, Leslie HM, Neeley E, Pauly D, Polasky S, Ris B, Martin KS, Stone GS, Sumaila UR, Zeller D (2012) An index to assess the health and benefits of the global ocean. Nature 488:615-622

Holsten A, Kropp JP (2012) An integrated and transferable climate change vulnerability assessment for regional application. Nat Hazards 64:1977-1999

IPCC (2007) Contribution of Working Group II to the fourth assessment report of the intergovernmental panel on climate change. Cambridge University Press, Cambridge, UK

IPCC (2012) Managing the risks of extreme events and disasters to advance climate change adaptation. A special report of working groups $\mathrm{i}$ and ii of the intergovernmental panel on climate change, Cambridge University Press, Cambridge and New York

IPCC (2014) Climate change 2014: impacts, adaptation, and vulnerability. Part A: global and sectoral aspects. Contribution of Working Group II to the fifth assessment report of the Intergovernmental Panel on Climate Change, Cambridge University Press, Cambridge, United Kingdom and New York, NY, USA

Marshall NA, Marshall PA, Tamelander J, Obura D, Malleret-King D, Cinner JE (2010) A framework for social adaptation to climate change: sustaining tropical coastal communities and industries. IUCN, Gland, Switzerland

Moss RH, Malone EL, Brenkert AL (2001) Vulnerability to climate change: a quantitative approach, Joint Global Change Research Institute. PNNL-SA-33642. Pacific Northwest National Laboratory, Washington

Mucke P (2012) WorldRiskReport 2012: environmental degradation increases disaster risk worldwide alliance development works, Berlin

Nurse LA, McLean RF, Agard J, Briguglio LP, Duvat-Magnan V, Pelesikoti N, Tompkins E, Webb A (2014) Small islands. Cambridge University Press, Cambridge, United Kingdom and New York, NY, USA

O’Brien K, Leichenko R, Kelkar U, Venema H, Aandahl G, Tompkins H, Javed A, Bhadwal S, Barg S, Nygaard L, West J (2004) Mapping vulnerability to multiple stressors: climate change and economic globalization in India. Glob Environ Chang 14:303-313

OECS (Organisation of East Caribbean States) (2004) Grenada: macro socio-economic assessment of the damages caused by hurricane Ivan. OECS, Castries, St. Lucia

Preston BL, Westaway RM, Yuen EJ (2011) Climate adaptation planning in practice: an evaluation of adaptation plans from three developed nations. Mitig Adapt Strateg Glob Chang 16:407-438

Shepard CC, Agostini VN, Gilmer B, Allen T, Stone J, Brooks W, Beck MW (2012) Assessing future risk: quantifying the effects of sea level rise on storm surge risk for the southern shores of Long Island, New York. Nat Hazards 60:727-745

Smit B, Wandel J (2006) Adaptation, adaptive capacity and vulnerability. Glob Environ Chang 16:282-292

Smith JB, Dickinson T, Donahue JDB, Burton I, Haites E, Klein RJT, Patwardhan A (2011) Development and climate change adaptation funding: coordination and integration. Clim Pol 11:987-1000

Wongbusarakum S, Loper C (2011) Indicators to assess community-level social vulnerability to climate change: an addendum to SocMon and SEM-Pasifika regional socioeconomic monitoring guidelines

Yohe G, Tol RSJ (2002) Indicators for social and economic coping capacity-moving toward a working definition of adaptive capacity. Glob Environ Chang 12:25-40

Young IR, Zieger S, Babanin AV (2011) Global trends in wind speed and wave height. Science 332:451-455 